\title{
IDENTIFIKASI BAKTERI Vibrio $s p$ DALAM HEPATOPANKREAS UDANG VANNAMEI (Litopenaeus vannamei ) PADA TAMBAK YANG DIBERI PROBIOTIK DI TAMBAK SAMPANG TIGO KELURAHAN DEGAYU KOTA PEKALONGAN
}

\author{
Ike Fatmala, Hadi Pranggono, Linayati \\ Program Studi Manajemen Budidaya Perairan \\ Fakultas Perikanan, Universitas Perikanan
}

\begin{abstract}
Shrimp vannamei (Litopenaeus vannamei) is a kind of shrimp that has important economic value in Indonesia, one of the inhibiting factors in increasing shrimp production is a disease caused by bacteria vibrio sp. This disease can cause a high death. This study aims to identify and quantify the number of Vibrio sp bacteria colonies in the hepatopancreas shrimp vannamei in ponds given probiotics, carried out in Sampang Tigo Ponds, Degayu -Pekalongan and Central Fish Ponds Brackish Water Aquaculture (BBPBAP), Jepara. This study was conducted on Monday 13 November 2017 to Wednesday April 25 2018. The study was conducted on a pond with a density of 100 and 116 tail / $\mathrm{m} 3$. The data of the research results were analyzed descriptively with the help of graphs and tables. The results showed that the sample of each plot of bacterial colonies exceeded the threshold, that is the average number of vibrio sp bacterial colonies on hepatopancreas shrimp T2 3,96 x $10^{6} \mathrm{CFU} / \mathrm{ml}$ and T3 plots $1,46 \times 10^{6} \mathrm{CFU} / \mathrm{ml}$ followed by shrimp morphological changes that have clinical signs of vibrio sp bacteria, the state of unbalanced water quality supports the bacterialgrowth.
\end{abstract}

Keywords: Cultivation, Vannamei shrimp, Vibrio sp, Density

\section{PENDAHULUAN}

Potensi produksi udang di Indonesia dari tahun ke tahun terus mengalami peningkatan. Perkembangan kegiatan budidaya perikanan yang pesat dengan penerapan sistem intensif telah memunculkan permasalahan berupa penurunan daya dukung tambak bagi kehidupan ikan/udang yang di budidayakan. Terjadinya serangkaian serangan penyakit menjadi dampak lanjutan yang di timbulkan yang dapat menyebabkan kerugianbesar.

Penerapan teknologi budidaya dengan berpedoman pada kaidah keseimbangan ekosistem merupakan solusi untuk mencegah kerusakan yang lebih serius, diantaranya adalah melalui aplikasi probiotik yang mempunyai kemampuan dalam mempertahankan kualitas air serta menghambat pertumbuhan dari mikroorganisme patogen (Suyanto \& Markus,2010).

Penyakit yang disebabkan oleh mikroorganisme patogen baik bakteri, virus atau protozoa merupakan salah satu faktor pembatas dalam budidaya udang Vannamei. Penanggulangan dan pencegahan penyakit udang dapat melalui peningkatan sistem pertahanan tubuh yaitu dengan menggunakan imunostimulan, vitamin dan hormon (Ridlo \& Rini, 2009). Untuk mengatasi penyakit Vibriosis diperlukan adanya deteksi awal tentang kandungan jumlah bakteri terutama bakteri Vibrio sp pada tambak udang. Dengan mengetahui kondisi kandungan bakteri maka dapat petani tambak dapat mendeteksi adanya penurunan kualitas air secara biologi. Pemberian probiotik merupakan salah satu upaya yang banyak dilakukan untuk menekan jumlah bakteri pathogen seperti Vibrio di air.

Mengingat pentingnya tingkat kesehatan udang dalam usaha budidaya, maka deteksi dini tentang kondisi kesehatan udang vannamei sangat diperlukan. Atas dasar 
pemikiran tersebut, maka di lakukan studi kasus tentang Analisis perkembangan bakteri Vibrio $s p$ dalam hepatopankreas udang Vannamei pada tambak yang diberi probiotik maupun tidak.

Tujuan penelitian ini adalah untuk mengidentifikasi bakteri Vibrio $s p$ dalam hepatopankreas udang Vannamei pada tambak yang diberi probiotik, dan untuk mengetahui jumlah kepadatan koloni bakteri Vibrio sp dalam hepatopankreas udang pada tambak yang diberi probiotik. Penelitian ini dilakukan di Balai Besar Perikanan Budidaya Air Payau (BBPBAB) Jepara dan tambak Sampang Tigo kelurahanDegayu Kota Pekalongan. Waktu penelitian dilaksanakan pada tanggal 13 November 2017 sampai pada tanggal 25 April 2018.

\section{TINJAUAN PUSTAKA}

Penyakit vibriosos pada udang baik di pembenihan maupun di tambak merupakan salah satu jenis penyakit yang sering menyebabkan kerugian besar akibat kematian yang ditimbulkan. Penyakit ini disebabkan oleh bakteri Vibrio $s p$. beberapa jenis bakteri Vibrio yang menyebabkan penyakit yaitu Vibrio harveyi, Vibrio parahaemoliticus, Vibrio alginoliticus, Vibrio anguilarum (Effendi, 2002). Identifikasi Vibrio parahemoliticus dalam tambak intensif maupun tradisional menunjukan hasil positif. Hal ini diduga akibat cara penerapan budidaya ikan yang baik belum optimal. Menurut Sardjito $d k k$ (2012) Gejala klinis udang yang terserang vibriosis adalah terdapat melanoso pada tubuh, terdapat bercak putih, telson serta ekor bewarna merah. Bakteri Vibrio sp merupakan jenis patogen yang menginfeksi dan menyebabkan penyakit pada kondisi udang yang lemah dan lingkungan yang ekstrim.

\section{METODE PENELITIAN}

Penelitian ini tentang identifikasi bakteri Vibrio sp dalam hepaktopankreas udang vannamei (Litopenaeus vannamei) pada tambak yang diberi probiotik di tambak Sampang Tigo Kelurahan Degayu Kota Pekalongan menggunakan metode penelitian deskriptif analitik dengan studi observasional untuk memberikan gambaran mengenai penelitian yang dilakukan dengan mengamati kondisi - kondisi yang terjadi melalui observasi secara langsung.

Metode pengumpulan data dilakukan melalui observasi, dokumentasi dan wawancara. Data yang diambil antara lain kontrol kualitas air, kontrol pakan serta pengujian dan perhitungan jumlah koloni bakteri Vibrio sp dalam hepatopankreas udang Vannamei.

Proses pengolahan data untuk perhitungan koloni bakteri maupun pemeliharaan udang menggunakan pemberian simbol berupa angka atau biasa disebut dengan kode, lalu melakukan klasifikasi terhadap coding yang dilakukan. Data kode sesuai dengan analisis yang dibutuhkan kemudian dilakukan tabulasi.

Analisis data yang digunakan adalah analisis data kualitatif yaitu melukiskan fakta, kenyataan atau informasi data berdasarkan hasil penelitian yang berbentuk penjelasan. Analisis data kualitatif merupakan bentuk analisis yang tidak menggunakan matematik, statistik dan ekonomi ataupun bentuk bentuk lainnya. Analisis data yang dilakukan terbatas pada teknik pengolahan data yang selanjutnya peneliti melakukan uraian dan penafsiran. Berdasarkan analisis tersebut akan ditarik kesimpulan secara induktif, yaitu cara berfikir dalam mengambil suatu kesimpulan terhadap permasalahan yang umum didasarkan fakta fakta yang bersifat khusus. 
Penelitian dilakukan pada tambak dengan kepadatan 100 dan116 ekor $/ \mathrm{m}^{3}$. Perlakuan yang diujikan adalah perhitungan jumlah koloni bakteri Vibrio sp pada sampel hasil penyisiran sampling jala dari setiap petak dan pengukuran parameter kualitas air yang meliputi $\mathrm{pH}$, salinitas, dan kecerahan secara insitu, sedangkan Hardness, alkalinitas, Nitrit, Ammonia, TOM (total organic matter), jumlah plankton, bakteri dan vibrio $s p$ dilakukan tiap minggu sebelum dan selama pemeliharaan

Metode penentuan jumlah sampling jala dan padat tebar udang vannamei adalah sampling jala tebar (Falling gear) kemudian dilakukan penyisiran. Luas penebaran jala setiap kali sampling adalah 0,2\% dari total luas tambak (Suyanto dan Enny, 2009). Maka frekuensi penebaran jala setiap kali sampling dapat dihitung dengan rumus sebagai berikut : Luas Jala $=\pi \times$ r2, Luas Sampling $=0,2 \% \times$ Luas petak, Frekuensi penebaran Jala = Luas Sampling dibagi Luas Jala. Udang vannamei hidup pada kolom air tambak, sehingga rumus perhitungan kepadatan udang adalah: Padat tebar = Jumlah tebar /Volume air.

\section{HASIL DAN PEMBAHASAN}

\subsection{Identifikasi Bakteri Vibrio sp}

Hasil penelitian menunjukkan bahwa kedua petak positif terserang bakteri Vibrio $s p$

Tabel 1 Jumlah koloni yang terdapat dalam hepatopankreas

\section{Total Vibrio sp $(\mathrm{CFU} / \mathrm{ml})$}

\begin{tabular}{cccc} 
NO & $\underline{\mathbf{T 2}}$ & $\underline{\mathbf{T 3}}$ \\
\hline 1 & & $1,0 \times 10^{6}$ & $2,7 \times 10^{6}$ \\
2 & & $4,0 \times 10^{6}$ & $3,3 \times 10^{6}$ \\
3 & & $4,9 \times 10^{6}$ & $8,7 \times 10^{5}$ \\
4 & $7,5 \times 10^{6}$ & $4,4 \times 10^{5}$ \\
5 & $2,4 \times 10^{6}$ & $2,0 \times 10^{4}$ \\
\hline Rata-rata: & $3,96 \times 10^{6}$ & $1,46 \times 10^{6}$
\end{tabular}

Sumber : Penelitian 2018

Tabel 2 Jumlah mikrobiologi dalam air tambak

\section{Mikro T2}

\begin{tabular}{cccc} 
DOC & Vibrio & Bakteri & Vibrio \% \\
\hline H- & 0 & 20100 & 0 \\
10 & 0 & 3900 & 0 \\
20 & 0 & 130.600 & 0 \\
31 & 490 & 193.000 & 0,002539 \\
43 & 860 & 140.000 & 0,006143 \\
55 & 190 & 37.100 & 0,005121 \\
63 & 150 & 77.000 & 0,001948
\end{tabular}

Sumber : Penelitian 2018 
Tabel 3 Jumlah Mikrobiologi dalam air tambak

\section{Mikro T3}

\begin{tabular}{cccc} 
DOC & Vibrio & Bakteri & Vibrio \% \\
\hline H- & 0 & 13100 & 0 \\
10 & 0 & 2000 & 0 \\
20 & 0 & 83100 & 0 \\
31 & 260 & 41.000 & 0,006341 \\
43 & 1100 & 234000 & 0,004701 \\
55 & 10 & 96100 & 0,000104 \\
63 & 0 & 432000 & 0
\end{tabular}

Sumber : Penelitian 2018

Minggu Ke-7 (1x 10²)

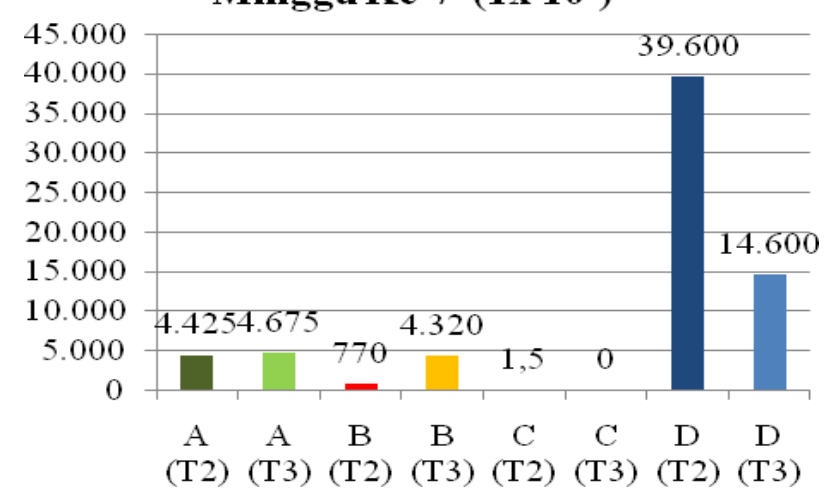

Ket : A (Plankton), B (Total bakteri pd air), C (Vibrio sp pd air), D (Vibrio sp pdhepatopankreas)

Gambar 1 Perhitungan KoloniBakteriVibrio $s p$

Tabel 1 menunjukkan bahwa pada petak T2 memiliki pertumbuhan bakteri Vibrio $s p$ lebih tinggi dari pada petak T3. Hal ini dikarenakan semakin padat jumlah tebarnya maka akan semakin mudah udang stress apabila terjadi kondisi lingkungan yang tidak stabil. Padat tebar yang tinggi serta pemberian pakan yang banyak dapat menurunkan kondisi kualitas air. Sisa pakan yang tidak termanfaatkan sehingga menumpuk pada dasar sedimen tambak dan tidak terakumulasi pada media air dapat meningkatkan populasi bakteri Vibrio sp pada sedimen tambak (Arafani,2016).

BakteriVibrio sp ketika jumlah kelimpahannya mencapai lebih dari1,4 x 10 $\mathrm{CFU} / \mathrm{ml}$ merupakan kondisi yang tidak menguntungkan bagi udang karena dapat menyebabkan udang sakit bahkan mengalami kematian (Kurniawan, dkk., 2014 ). Hasil penelitian menunjukkan bahwa keberadaan bakteri probiotik mampu menekan pertumbuhan bakteri Vibrio sp. Hal ini juga dikemukakan oleh Ervia, dkk (2010) bahwa tanpa pemberian probiotik (kontrol) populasi bakteri Vibrio sp lebih tinggi dari pada perlakuan dengan probiotik.

Faktor lingkungan yang tidak mendukung mengakibatkan produksi antibiotik berkurang sehingga imunitas atau kekebalan tubuh udang vannamei terhadap serangan penyakit berkurang (Yuni, dan Yunita, 2015). 


\subsection{Parameter Kualitas Air}

Pengukuran parameter kualitas air yang dilakukan dalam setiap hari meliputi kecerahan, $\mathrm{pH}$ air, DO dan salinitas. Perubahan $\mathrm{pH}$ merupakan efek langsung dari fotosintesis yang menggunakan $\mathrm{CO}_{2}$ selama proses tersebut, turunnya konsentrasi $\mathrm{CO}_{2}$ akan menurunkan konsentrasi $\mathrm{H}^{+}$sehingga menaikkan $\mathrm{pH}$ air. Oleh sebab itu pada petak $\mathrm{T} 2$ mengalami penurunan $\mathrm{pH}$ lebih tinggi dari pada petak $\mathrm{T} 3$ yang kepadatannya lebih sedikit.

Hasil pengamatan salinitas air tambak udang vannamei selama pemeliharaan terlihat bahwa kisaran salinitas dari kedua tambak relatif rendah. Udang vannamei dapat tumbuh optimal pada kisaran salinitas antara 15 - 25 ppt dan dapat bertahan hidup pada kisaran $0-50 \mathrm{ppt}$, hal ini karena udang vannamei memiliki sifat euryhaline yangtinggi (Syafaat, 2012). Data penelitian menunjukkan DOC 55 salinitas kedua tambak berkonsentrasi optimal dan disertai dengan penurunan jumlah koloni bakteri Vibrio sp pada air tambak.

Tabel 4 Kualitas air tambak

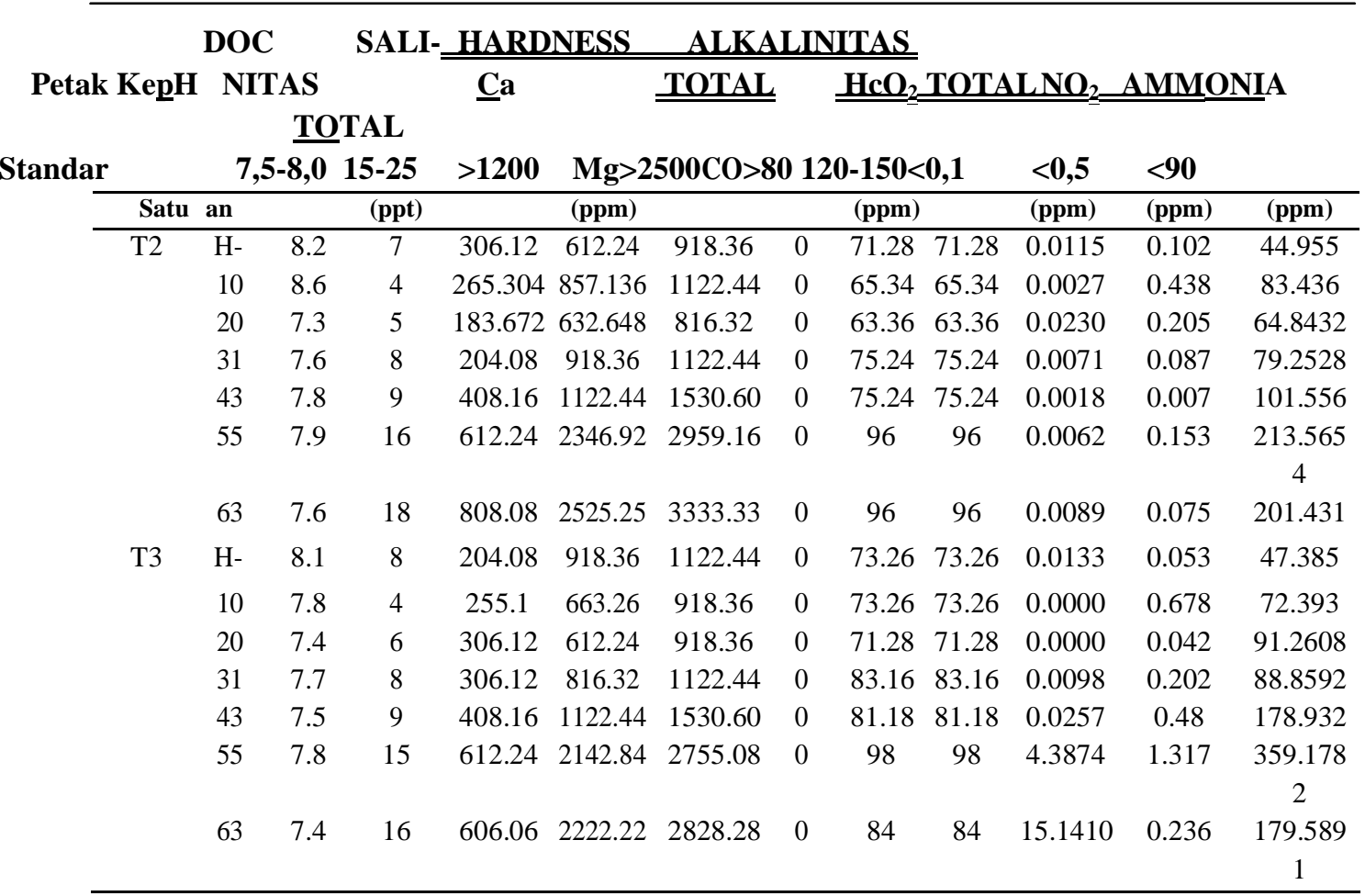

Sumber : Penelitian, 2018 
Dilihat dari hasil penelitian menunjukkan bahwa nilai total hardness lebih besar dari alkalinitas, sehingga sebagian kalsium dan magnesium bereaksi dengan sulfat, klor, silikat, dan nitrat (Supomo, 2015). Pada DOC 55 dan 63 pada kedua petak yang memenuhi target. Alkalinitas adalah kapasitas air untuk menetralkan asam. Air tambak yang mempunyai alkalinitas rendah akan berpengaruh terhadap pertumbuhan udang. Hal ini terkait dengan pengaruh alkalinitas terhadap kesediaan hara bagi fitoplankton sebagai makanan. Dengan meningkatnya alkalinitas akan menyebabkan terlepasnya unsur fosfor dan meningkatkan tersedianya unsur karbon untuk proses fotosintesis fitoplankton (Suwarsih, dkk., 2016). Hasil pengukuran alkalinitas di air tambak berkisar antara 63,36 - 98 ppm. Jadi alkalinitas belum cukup optimal untuk budidaya udang Vannamei. Nilai kisaran alkalinitas cukup optimal untuk budidaya udang antara $120-150$ ppm.

Hasil pengamatan nitrit pada kedua petak menunjukkan kandungan $\mathrm{NO}_{2}$ pada tambak masih memenuhi standar baku mutu yang ditetapkan, yaitu $<0,1 \mathrm{ppm}$.. Hasil pengamatan pada kedua petak konsentrasi ammonia masih dibawah standar sehingga tidak menyebabkan toksisitas, konsentrasi ammonia yang mengalami penurunan dikarenakan banyak dikonsumsi oleh bakteri maupun plankton, bakteri heterotrof sangat aktif menggunakan ammonia terlebih ketika ketersediaan karbohidrat dan oksigen memenuhi (Gunarto, $d k k$., 2009).

TOM (bahan organik total) menggambarkan kandungan bahan organik total suatu perairan yang terdiri atas bahan organik terlarut, tersuspensi dan koloid. Hasil pengamatan yang didapat pada petak T2 konsentrasi tinggi pada DOC $43(101,55$ ppm), 55 (213,56 ppm)dan63 (201,43 ppm) sedangkan pada petak T3 pada DOC 20 (91,26 ppm), 43 (178,9 ppm), 55 (359,2 ppm),dan63 (179,9 ppm). Batas maksimal skala budidaya udang adalah $<90$ ppm sehingga pada konsentrasi ini terdapat di petak T3 yang mengalami masalah.

Jumlah oksigen yang dibutuhkan untuk pernapasan udang bergantung ukuran, suhu, dan tingkat aktivitasnya. Batas minimum yang ditentukan bagi tambak udang dalam 3 ppm. Kandungan oksigen terlarut optimum untuk budidaya udang di tambak lebih besar 5 ppm. Hasil pengukuran oksigen terlarut di tambak berkisar antara 5,4-9,1 ppm. Dengan demikian oksigen terlarut cukup baik.

\section{SIMPULAN DAN SARAN}

Hasil identifikasi bakteri Vibrio sp dalam hepatopankreas udang vannamei (Litopenaeus vannamei) pada kedua tambak yang diberi probiotik positif mengandung bakteri vibrio sp. Jumlah rata - rata koloni bakteri Vibrio sp dalam hepatopankreas udang pada tambak T2 ditemukan sebanyak 3,96 x $10^{6} \mathrm{CFU} / \mathrm{ml}$ dan tambak T3 sebanyak 1,46 x $10^{6} \mathrm{CFU} / \mathrm{ml}$.

Berdasarkan hasil penelitian yang telah dilakukan, disarankan untuk melakukan penelitian lanjutan. tentang identifikasi keberagaman jenis spesies bakteri yang terdapat pada hepatopankreas, usus maupun haemolimp udang vannamei dengan kondisi lingkungan terkontrol.

Saran yang dapat diberikan untuk pembudidaya adalah meningkatkan kinerja kontrol kualitas air dan monitoring penyakit serta perlunya menambahkan bakteri probiotik yang mengandung Bacillus sp, Lactobacilus sp dan bakteri menguntungkan lainnya dalam treatment kualitas air pada tambak untuk menekan pertumbuhan bakteri Vibrio sp dalam air. 


\section{DAFTAR PUSTAKA}

Arafani, Lulu dkk. 2016. Pelacakan Virus bercak putih pada udang Vananname di Lombok dengan real time PCR. Nusa Tenggara Barat. Jurnal Veteriner. Maret 2016 vol 17 no 1 hal 88-95

Arif, Lukman ,Dkk 2016. Pengaruh pemberian probiotik berbeda pada pakan terhadap retensi lemak udang vanname. Litopenus vaname ' Surabaya. Jurnal of aquaculture and Fish health Vol 6

Effendy, Parsiholan N. 2002. Ekstraksi dan manfaat Ekstrak Mangrove ( Sonneratia alba dan Sonneratia caseolaris) Sebagai bahan alami anti bakteri : Pada Patogen udang windu, Vibrio harveyi. Penerbit Institut Pertanian bogor

Gunarto dkk. 2009. Aplikasi dosis fermentasi probiotik berbeda pada budidaya udang Vanname (Litopennus Vanname) pola intensif. Sulawesi Selatan. Jurnal Ris Akuakultur Vol 4 No 2.

Kilawati, Yuni \& Yunita M. 2015. "Kualitas Lingkungan Tambak Intensif Litopenaeus Vannamei Dalam Kaitannya dengan Prevelensi Penyakit White Spot Syndrome Virus". Malang. Research Journal Of Life Science. E-Issn : 2355-9926 April-2015 Volume 02 No. 01.

Kurniawan,Koko dkk 2014. Uji pathogenesis dan gambaran histology hepatopancreas infeksi bakteri vibrio pathogen secara penyuntikan. Jepara Semnaskan UGM/ Poster. Penyakit Ikan dan Kesehatan Lingkungan

Nur, Muhammad Syafaat, $d k k$. 2012. "Dinamika kualitas air pada budidaya udang vannamei (Litopenaeus vannamei) semi- intensif dengan teknik pergiliran pakan". Sulawesi Selatan. Hlm488. Prosiding Indoaqua -Inovasi Teknologi Akuakultur 2012.

Ridlo, Ali dan Rini Pramesti. 2009. 'Aplikasi Rumput lautSebagai Agen Imunostimulant Sistem pertahanan non specisfik pada Udang ( Litonneus vannamei). Semarang. Pg 133. Jurnal Ilmu Kelautan Vol 14 (3) : 133-137

Sardjito, dkk 2012. Aplication of Repetitive Sequience -Based PCR on the richness of Vibrio on Tiger shrimp ( panaeus monodon Fa) 15 (3): 303-309

Supomo, 2015. Manajemen Lingkungan untuk akuakulyut. Plantaxia. Surabaya

Suryanto, Hidayat. S dan Markus Mangampa. 2010. “Aplikasi Probiotik Dengan Konsentrasi Berbeda Pada Pemeliharaan Udang Vaname (Litopenaeus vannamei)". Sulawesi Selatan.239. Penerbit: Balai Riset Perikanan Budidaya Air Payau.

Suwarsih ,dkk. 2016. Kondisi Kualitas air pada budidaya udang di tambak wilayah pesisir kecamatan Palang Kabupaten Tuban. Malng. Prosiding Semiar Nasional Kelautan. 2016. Universitas Trunojoyo.

Suwarsih, $d k k$. 2016. "Kondisi kualitas air pada budidaya udang di tambak wilayah pesisir kecamatan palang kabupaten tuban". Malang. Prosiding Seminar Nasional Kelautan 2016 UniversitasTrunojoyo Madura, 27 Juli 2016.

Suyanto, Rachmatun dan Enny Purbani Takarina. 2009. 'Panduan Budidaya Udang Windu”. Penebar Swadaya Depok

Velyan, Rezqi S.K. 2009. "Pengaruh Tiga Cara Pengolahan Tanah Tambak terhadap Pertumbuhan Udang Vaname Litopenaeus Vannamei”. Bogor. Hlm 9. Penerbit: Institut Pertanian Bogor. 